\title{
Government Help in Upbringing Children and its Significance in the Formation of the Attitudes of Single Parents Towards Employment
}

Ewa Jurczyk-Romanowska / e-mail: ewa.jurczyk-romanowska@uwr.edu.pl Institute of Pedagogy, University of Wroclaw, Poland.

Jurczyk-Romanowska, E. (2017). Government Help in Upbringing Children and its Significance in the Formation of the Attitudes of Single Parents Towards Employment. Czech-Polish Historical and Pedagogical Journal, 9/2017/2, 46-55. doi: 10.5817/cphpj-2017-0012

In the paper, an analysis is presented of the new solutions in government support for the opportunities for providing for the needs of children in families introduced in Poland, which have become a flag electoral project of the right-wing political party Law and Justice (Prawo i Sprawiedliwość). After the parliamentary elections of 2015 the work on a new bill began and in the first quarter of 2016 the Act on government help in upbringing children went into effect. The regulation was intended as a countermeasure to the demographic crisis in Poland. According to this new legal regulation, single parents raising one child may not be able to collect the new benefit. This regulation encourages single parents to leave employment and live on benefits from social services and child-support benefits.

Key words: demographic crisis; child-support benefits; government help; providing for the needs of children

\section{Demographic crisis in Poland}

Poland, as well as other European countries, is facing the problem of the aging of the population, resulting from the prolonged lifespan and constantly decreasing birth rate. When discussing the rate of natural increase, it needs to be defined as the difference between the number of live births and the number of deaths. Recently the rate of natural increase presented itself as follows: in 2013: -0.1 ; in 2014: $-0.03 ;^{1}$ in 2015: -0.7 ; and in $2016-0,6{ }^{2}$ This data proves that in the recent years the lowest rate of natural increase in the history of post-war Poland was registered (cf. Fig. 1).

1 http://stat.gov.pl/files/gfx/portalinformacyjny/pl/defaultaktualnosci/5468/12/5/1/ podstawowe_informacje_o_rozwoju_demograficznym_polski_do_2014.pdf 


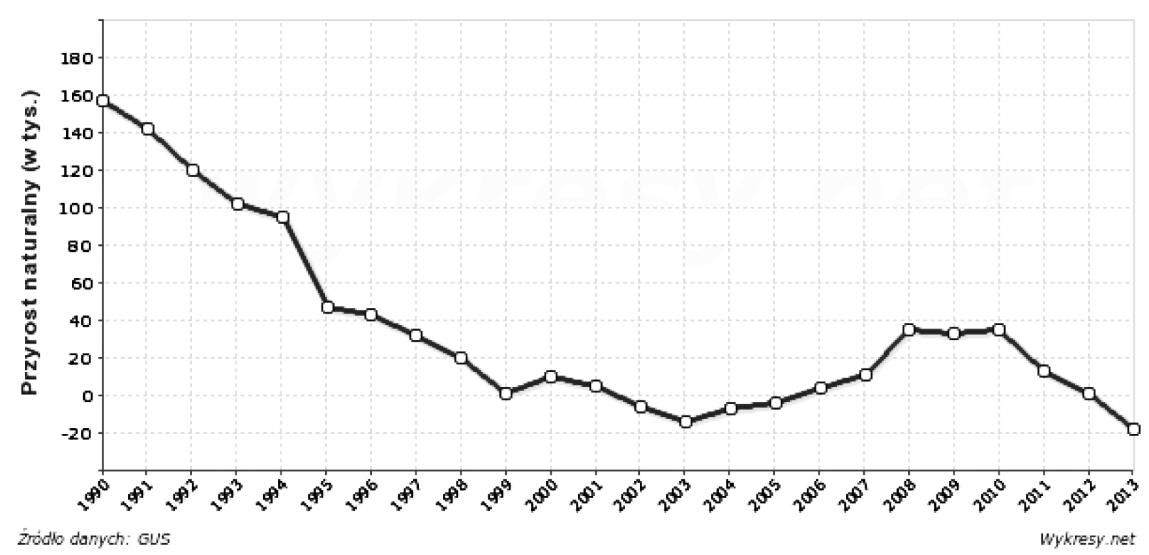

Rate of natural increase (M)

Fig. 1. The rate of natural increase in Poland. Source: http://www.wykresy.net/liniowe/przyrost-naturalny-w-polsce-ostatnie-24-lata.html

To compare - in 2016 the highest rate of natural increase was registered in South Sudan (3.92). The first European country to have made its way on the list is Ireland (1.2) occupying 95 position (!). Poland is at position 209 with a rate of -0.11 . The list of the countries in the ranking developed by the Central Intelligence Agency has 235 positions and the lowest registered rate is that of the Cook Islands $(-2.88) .{ }^{3}$ In light of these statistics, the severity of the demographic crisis in Poland becomes apparent. The differences in the results for 2016 between those of the Central Intelligence Agency (CIA) and Poland's Central Statistical Office (Gtówny Urząd Statystyczny, hereinafter: GUS) arises from the methodology of calculating the rate of natural increase. In the data presented by GUS only live births and deaths were taken into account, whereas in the CIA data migration of the population was also included. The above data show the severity of the problem that Poland has with the negative rate of natural increase. In the global scale, the loss is one of highest in the world.

That is why the government of Poland has been presented with the necessity to undertake actions aimed to increase the number of children born in Poland and to minimise the effects of emigration. In the present paper, the flag programme of the current government formed by the right-

3 ttps://www.cia.gov/library/publications/the-world-factbook/rankorder/2002rank.html 
wing Law and Justice party (Prawo i Sprawiedliwość, hereinafter: PiS) which was intended as a countermeasure to the growing demographic crisis in Poland is discussed.

\section{Assumptions of the Family $500+$ programme}

The proposal of the Family $500+$ in 2015 became one of the main points of the electoral programme of Polish right-wing politicians organised into Law and Justice and it was the subject of heated discussion in the media. New child-support benefits were to become a remedy for Polish demographic problems and to improve the difficult situation of the families. ${ }^{4}$ Immediately after gaining political power PiS initiated actions aimed to fulfil their electoral promise while at the same time emphasising that the programme is indeed the answer to the promises made to all the Poles before the elections. As a result, the proper act went into effect in the first quarter of 2016.

The legal basis for the "Family 500+" programme is the act of February 11, 2016 on government help in upbringing children ${ }^{5}$ which defines the conditions of acquiring the right to receive child-support benefits and the guidelines for granting and distributing the benefit. ${ }^{6}$ The right to receive the benefit is granted to Polish citizens and in some cases also foreigners. ${ }^{7}$ What is crucial in the understanding of the controversy surrounding the introduced programme is the analysis of the problems connected with the terms used in the act which defines the beneficiaries and the income criteria.

Aim of the child-support benefit. According to the act, the aim of the child support benefit is "the partial coverage of the expenses made in upbringing a child, including care for the child and fulfilling their needs". 8 It is declared that "the government programme Family $500+$ is aimed to

4 Uncertain future of the "500 PLN per child" project] (2015). Retrieved from http://www. newsweek.pl/polska/projekt-500-zl-na-dziecko-obietnice-wyborcze-pis-rzad-pisartykuly,373804,1.html.

5 The act of February 11, 2016 on government help in upbringing children (2016). Journal of Laws of 2016, pos. 195.

6 Ibidem, art. 1.

7 Ibidem, art. 2. Pertains to circumstances where the regulations on the coordination of the systems of social security arising from bilateral international agreements on social security for foreigners residing in Poland, on the basis of temporary permits as well as those with residence permits with the "access to the labour market" clause apply. Ibidem, art. 4. 1 
help in upbringing children by granting child-support benefits". 9 In its assumptions, the programme, apart from improvement of the situation of Polish families, is to boost the birth rate, which is to be the answer to the demographic problems of Poland.

Beneficiaries of the programme. The benefit, in the amount of 500 PLN per month per child in the family, can be collected by the mother, the father, the actual guardian, or the legal guardian of a child under 18 years of age. ${ }^{10}$ According to the legal definitions found in the act of February 11, 2016 on government help in upbringing children:

- "child" is one's own child, the child of a spouse, adopted child or a child in whose case adoption proceedings are underway, or a child under legal guardianship; ${ }^{11}$

- "first child" is the only or the oldest of children in the family under 18 years of age; in the case of children born on the same day, month, and year, being the oldest children in a family under 18 years of age, first child is one of the two children selected by a parent, an actual guardian, or a legal guardian; ${ }^{12}$

- "family" is the respective members of the family: spouses, parents of the children, actual guardian of the child and individuals residing together with them, dependents under the age of 25 , as well as children over the age of 25 with severe disabilities if these responsibilities lead to the acquiring of benefits from social services. ${ }^{13}$ Not included as family members are children under the care of the legal guardian, married children, as well as adult children who have children of their own. ${ }^{14}$ In the case of a court ruling placing the child under the alternate guardianship of divorced or separated parents, or parents not residing together, the child is a member of the families of both the parents; ${ }^{15}$

- "actual guardian of a child" is an individual who has submitted an application for adoption of the child to a court of law; ${ }^{16}$

- "single parent" is an unmarried man or woman, a widow, a widower, a person separated according to a valid court ruling, a divorced

9 http://www.program500plus.pl/zasady-programu.html

10 The act of February 11, 2016 on government help in upbringing children (2016). Journal of Laws of 2016. pos. 195, art. 4. 2 and 4. 3.

11 Ibidem, art. 2, pt. 5.

12 Ibidem, art. 2, pt. 14 in accordance with art. 4, pos. 2.

13 Ibidem, art. 2, pt. 16.

14 Ibidem, art. 2, pt. 16.

15 Ibidem, art. 2, pt. 16.

16 Ibidem, art. 2, pt. 10. 
person unless they are raising at least one child together with the child's parent. ${ }^{17}$

Table 1. Types of families in Poland. Source: Łysoń P. (2014) Warunki życia rodzin w Polsce. Warszawa: GUS, p. 26.

\begin{tabular}{|c|c|c|c|c|c|c|c|c|}
\hline \multicolumn{9}{|c|}{ families } \\
\hline \multirow[t]{2}{*}{ total } & \multicolumn{3}{|c|}{ married couples } & \multicolumn{3}{|c|}{ informal relationships } & \multirow{2}{*}{$\begin{array}{l}\text { mothers } \\
\text { with } \\
\text { children }\end{array}$} & \multirow{2}{*}{$\begin{array}{l}\text { fathers } \\
\text { with } \\
\text { children }\end{array}$} \\
\hline & combined & $\begin{array}{l}\text { no } \\
\text { children }\end{array}$ & $\begin{array}{l}\text { with } \\
\text { children }\end{array}$ & combined & $\begin{array}{l}\text { no } \\
\text { children }\end{array}$ & $\begin{array}{l}\text { with } \\
\text { children }\end{array}$ & & \\
\hline \multicolumn{9}{|c|}{ in $M$} \\
\hline 10972,5 & 8153,2 & 2696,4 & 5456,8 & 316,5 & 145,2 & 171,3 & 2174,3 & 328,6 \\
\hline
\end{tabular}

The above legal definitions make it possible to precisely define who is considered a family member in light of the act, the terms "child" and "first child" are also clearly defined. The definitions of the last two terms are contrary to the common understanding of kinship. Differentiating between the first child in the family and other children arises from the differentiation of the rules on granting the benefits connected with the definition of the income criterion for the child-support benefit for the first child.

Income criterion for the acquiring of child-support benefit for the first child in the family is the family income per capita not exceeding 800 PLN, and if one of the children in a family is disabled 1,200 PLN. For each subsequent child, the benefit of 500 PLN is granted without an income criterion. ${ }^{18}$

Distribution of the benefit. According to the guidelines the child-support benefit is distributed in the pecuniary form, however, in the case when a justified suspicion arises as to wasteful spending of the funds or that the funds are not spent on good of the child the decision to: (1) stop paying the benefit in its entirety, (2) stop paying a part of the sum of the benefit, (3) grant the benefit in a different form, (4) grant a part of the benefit in a different form can be made. The persons collecting the benefit while not being legally entitled to it are obliged to return the funds in their entirety including legal interest. Regulations on execution proceedings in administration apply to undue benefits. ${ }^{19}$ The legal basis for altering the form in which the benefit is distributed is art. 9 of the act of February 11, 2016 on government help in

17 Ibidem, art. 2, pt. 16.

18 Ibidem, art. 4 and art. 5.

19 http://www.program500plus.pl/wysokosc-swiadczen.html 
upbringing children which states that "in the case of an individual who is entitled to acquire the benefit spending it wastefully or not according to the defined aims, the proper authority shall distribute the benefit entirely or partially in a different form or in the form of payments for services". ${ }^{20}$

In its further part the act of February 11, 2016 on government help in upbringing children settles the questions connected with the subjects realising the aims in the area of the child-support benefit, proceedings in cases of applications for the benefit, financing the Family 500+ programme and points out the necessary legal changes. However, to assess the help in upbringing children in single-parent families and the significance of the legal regulations in the formation of the attitudes of single parents towards employment, the problems discussed above are a sufficient basis for further discussion. The Family 500+ programme was promoted through a popular advertising campaign in the press, on the radio, and on the internet, websites dedicated to the promotion of the programme and to facilitating the benefit application process have been created. ${ }^{21}$ What is more, banks were employed in the servicing of the programme, alongside government administration. The banks were granted the right to apply for the benefit in the name of the willing beneficiaries.

\section{Structure of families in Poland}

On the basis of the data, published by the Central Statistical Office in $2014,{ }^{22}$ that is, in the last year before the works on the Family $500+$ programme were initiated, it is clear that the number of single parent families in Poland is significant. In the quoted report data from the National Census of Population and Residence of 2011 was used to outline the structure of the families in Poland, this being the most up-todate census. On the basis of this data, it can be stated that:

1) over a half of the population of Poland was made up of families with children (20416.3 M / $53.3 \%$ );

2) single parents - mainly single mothers - and their children made up to 1/6 of the population of Poland (mothers with children: $5248.4 \mathrm{M} /$ $13.7 \%$; father with children: $769 \mathrm{M} / 2 \%$ );

20 The act of February 11, 2016 on government help in upbringing children (2016). Journal of Laws of 2016, pos. 195. art. 9.

21 http://www.program500plus.pl/ and https://www.mpips.gov.pl/wsparcie-dla-rodzin-zdziecmi/rodzina-500-plus/pytania-i-odpowiedzi/

22 Łysoń P. (2014). Warunki życia rodzin w Polsce.Warszawa: GUS, p. 26. 
3) persons in informal relationships (adults and children) constituted altogether less than 1/40 of the population of Poland, and the number of informal relationships was lower than 1/25 of the number of marriages. ${ }^{23}$

According to the National Census of Population and Residence the structure of the families presents itself as follows:

Single parents with at least one dependent child constitute altogether $5.9 \%$ of all households. Single mothers made up $5.4 \%$ of all family households. ${ }^{24}$ At the same time, it needs to be noted that single parents (mainly mothers) would raise every fifth dependent child aged 0-24.25 Among all the types of family households with dependent children under the age of 24 married couples constituted the largest group $-80.7 \%$, the second largest group were mothers with dependent children $-10.1 \%$ of all the families with children under 24. Among all the married couples with children dependents those with one child constituted $41.7 \%$ (among married couples and informal relationships $42.8 \%$ ), with 2 children $-40.8 \%$ (among married couples and informal relationships 39.9\%), and with 3 children and more - $17.5 \%$ (among married couples and informal relationships $17.3 \%) .{ }^{26}$ The quoted report does not differentiate family households of single parents according to the number of children, which is why it is impossible to point out the exact percentage of single parents with one child. The age structure of children dependents of single parents is presented and on this basis, it can be stated that the highest percentage is comprised of children in the categories: $13-15$ years of age $(4,9 \%)$ and $7-12(4.8 \%)$. and the lowest percentage is made up of those aged $0-3$ (2.1\%). This stratification may be the result of the growing divorce rate. ${ }^{27}$

If the above structure of Polish families is supplemented with information on the opportunities to satisfy basic needs, that is, confirming the material status of the particular families what we are presented with is a difficult situation of single-parent families and those with high number of children. It turns out that basic dietary needs could not be satisfied in $8.5 \%$ of families with at least 3 children, $2.7 \%$ of families with 2 children and $1.9 \%$ of those with 1 child. When analysing the educational needs one can notice that they were not satisfied in $17.5 \%$ of families where a single parent raises at least 1 child. The second position is occupied by

23 Ibidem, p. 25.

24 Ibidem, p. 27.

25 Ibidem, p. 28.

26 Ibidem, p. 28.

27 Ibidem, p. 29. 
married couples with at least 3 children (15.5\% of families in this group cannot satisfy their children's educational needs). The lowest percentage pertained to married couples with 1 child $-3.4 \%$. Also in these two types of families, the percentage of resigning from extracurricular educational activities is the highest (in both the types it is over 30\%). So is the case with meeting other needs of the children, including those pertaining to health and living conditions. ${ }^{28}$ On this basis, it can be stated that the families which face the highest threat of poverty, which are unable to satisfy the children's basic needs, are families with at least 3 children and single parent families.

\section{Assessment of the Family $500+$ programme}

When comparing the regulations of the remaining part of the act of February 11, 2016 on government help in upbringing children with the information on the structure of families in Poland and their ability to satisfy basic needs it can be stated that:

1) About $58.3 \%$ of married couples with at least two children will be able to acquire the child-support benefit without the income criterion. When we take into account informal relationships the percentage of the families with two parents and at least two children is $57.2 \%$. The benefit shall be received for every second and further child in the family, regardless of the sources and level of income. The level of the benefit will be a multiple of 500 PLN and the number of children minus the first child.

2) Furthermore, in the case of the married couples discussed in point 1), that is, those constituting about $58.3 \%$ of all families, families with low income - i.e. not exceeding 800 PLN per family member (or 1,200 PLN if at least one child is disabled) - they will be able to apply for the benefit for the first child as well. Estimating the percentage of families which can apply for the benefit for the first child, on the basis of the data pertaining to the ability to satisfy basic needs, it is $30 \%$ of all the families with multiple children.

3) In the case of married couples with one child, constituting $41.7 \%$ (taking into account informal relationships 42.8\%) the verification of the income per family member will be necessary every time. Taking into account the ability to fulfil basic needs estimated in the research 
carried out by GUS the percentage reaches $3.4 \%$ of all married couples.

It needs to be emphasised that the mentioned estimates are forecasts. That is because there is no access to information about the precise structure of families in 2016 and on the subject of the ability to meet the income criteria by these families. That is why what was taken into account in the analysis was the latest population census as well as the latest GUS report that could be developed before the onset of the works on the Family 500+ programme. However, we ought also to bear in mind the aim of the benefit which is "the partial coverage of the expenses made in upbringing a child, including care for the child and fulfilling their needs". 29 Thus, the analysed data pertained to the families who are not able to fulfil their children's basic needs or those who struggle to do so.

When analysing the situation of married couples, it can be stated that numerous families in which both parents raise their children will receive government benefits. In the case of families with multiple children the benefits will be substantial. Each family with at least three children will receive at least 1,000 PLN monthly, which will raise the living standard of family members significantly. In the case of married couples with one child only a low percentage of families will be able to benefit from financial support.

The situation is quite different in the case of single parent families. This typically pertains to single mothers in Poland.

The situation of single parents with at least two children is analogous to that of the married couples and informal relationships - the benefit will be distributed for every second and further child. The quoted report does not contain, however, information about the percentage of single parents raising more than one child.

The situation of single parents raising one child is particularly difficult. When analysing the data on the needs it turns out that over $17.5 \%$ of those families are unable to satisfy basic educational needs, and over $30 \%$ cannot have their children participate in any extracurricular activities. Therefore, it can be estimated that about $1 / 3$ of single-parent families is in a difficult financial situation. At the same time, in this group it is difficult to meet the criterion of 800 PLN per family member, because the limit is exceeded due to minimum wage. According to the Decree of the Council of Ministers of September 11, 2015 on minimum wage since 01.01.2017 the minimum salary of a person in full-time employment is

29 The act of February 11, 2016 on government help in upbringing children (2016), Journal of Laws of 2016, pos. 195, art. 4. 1. 
$1,850 \mathrm{PLN},{ }^{30}$ which, after being divided among family members, exceeds the limit by 125 PLN. On this basis it can be concluded that a single parent with a child dependent who decides to be employed full-time shall be legally deprived of the opportunity to acquire the child-support benefit.

When juxtaposing the difficult financial situation of single parent families, as reported by GUS, with the guidelines of granting the childsupport benefits discussed above it can be stated that the author of the act has excluded this social group from the opportunity to receive this form of financial support dedicated to satisfying children's needs. What is also significant is that the cost of raising an only child is the highest. According to estimates raising a second child costs about $80 \%$ of the costs of raising an only child. With a subsequent child the cost is reduced by further $20 \%$, which is connected with the distribution of indirect costs (using the older child's things, different calculation of the costs of everyday life such as food, shelter, utilities). ${ }^{31}$ If one were also to point out that other benefits can be received from social services ${ }^{32}$ when a single parent is not in employment it can be stated that financially it makes more sense to remain unemployed and apply for benefits from social services. This also leads to the single parent having more time for their child. That is why it needs to be decisively concluded that this form of government help in upbringing children has negative impact on the formation of single parents' attitudes towards employment.

30 Decree of the Council of Ministers of September 11, 2015 on minimum wage

31 Surdej, A. - Gołębicka, A. - Kelm, H. - Sadowski, A. (2016). Koszty wychowania dzieci w Polsce 2016. Praca to bezpieczna rodzina: Raport Centrum im. Adama Smitha pod kierunkiem prof. dr hab. Alekandra Surdeja. Warszawa, Centrum im. Adama Smitha, p. 8.

32 Analysis of all the benefits exceeds the present paper, however, information on this subject can be acquired from social services. 